( Т. Ю. Киричок, д-р техн. наук, професор, Н. Л. Талімонова, канд. техн. наук, доцент, КПІ ім. Ігоря Сікорського, Київ, Україна, В. А. Баглай, генеральний директор Банкнотно-монетного двору НБУ, аспірант, КПІ ім. Ігоря Сікорського, Київ, Україна, Я. Ю. Талімонов, головний фахівець технологічного відділу

Банкнотної фабрики Банкнотно-монетного двору НБУ, аспірант, КПІ ім. Ігоря Сікорського, Київ, Україна

\title{
ДОСЛІДЖЕННЯ ЯВИЩА ПЕРЕБИВАННЯ ФАРБИ НА ПАПЕРІ СПЕЦІАЛЬНОГО ПРИЗНАЧЕННЯ, ВИГОТОВЛЕНОГО ЗА РІЗНИМИ ТЕХНОЛОГІЯМИ
}

Досліджено фізико-механічні, колірні характеристики двошарового банкнотного паперу, мікрогеометрію поверхні паперового полотна та явище перебивання Фарби на зворот відбитка.

Ключові слова: банкнотний папір; перебивання; друкарська фарба; мікрогеометрія поверхні паперу; колір.

\section{Постановка проблеми}

Для виготовлення вітчизняних банкнот передбачається використання нового двошарового паперу. Одношаровий банкнотний папір, що використовується на даний час, виготовляється із застосуванням меламіно-формальдегідних смол. Від якості проклейки залежить ряд характеристик паперу, зокрема, пористість, поглинаюча здатність, гладкість. Використання формальдегідів забезпечує високу якість проклейки паперу, але в той же час ця речовина $є$ алергеном $[1,2]$. В зв'язку з цим новий двошаровий папір було виготовлено за безформальдегідною технологією.

Зміна технології виготовлення паперу може суттєво вплинути на якісні характеристики відбит- ків, отриманих на ньому. Тому, варто дослідити вплив параметрів нового виду паперу на друкарсько-технічні властивості та якість поліграфічної продукції.

\section{Мета роботи}

Дослідження фізико-механічних і колірних характеристик двошарового банкнотного паперу, а також мікрогеометрії поверхні паперового полотна та перебивання фарби на зворотну сторону відбитка.

\section{Результати проведених досліджень}

Для проведення експериментальних досліджень було використано два види паперу для друку банкнот номіналом 10 гривень одно- та двошаровий, фізико-технічні характеристики яких було 


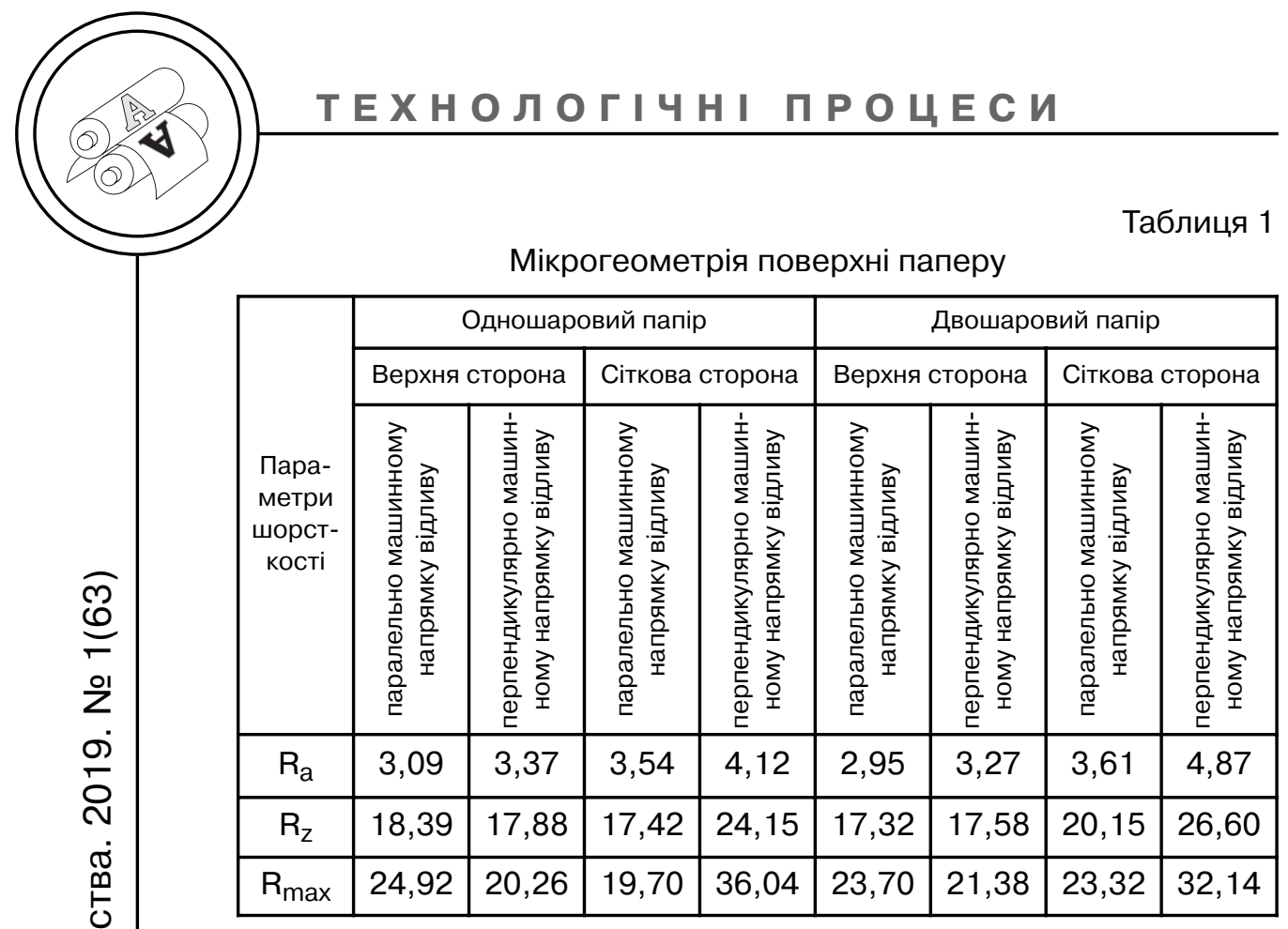

визначено експериментально [3]. Відбитки були виготовлені на цих паперах спеціальною півпрозорою фарбою трьох відтінків. Рецептура фарби була розроблена і виготовлена за допомогою програми Data Color $[4,5]$. Тестові відбитки були отримані у лабораторних умовах на прободрукарському приладі IGT Reprotest B.V.

Оскільки мікрогеометрія поверхні паперу суттєво впливає на повноту його контакту з друкарською формою, фарбосприйняття та ряд інших показників

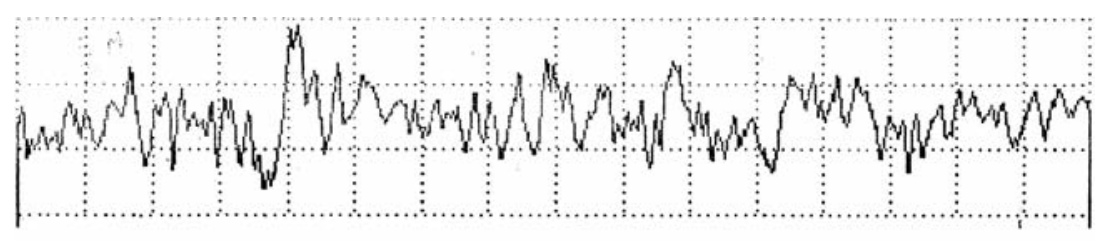

Рис. 1. Профілограма поверхні верхньої сторони одношарового паперу паралельно машинному напрямку відливу

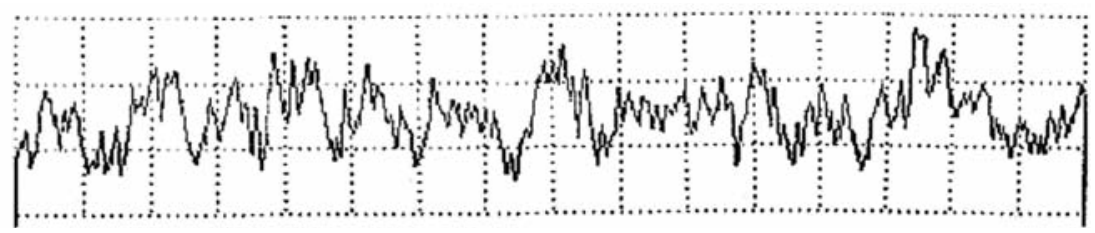

Рис. 2. Профілограма поверхні верхньої сторони одношарового паперу перпендикулярно машинному напрямку відливу 
[6], було визначено шорсткість паперу за допомогою профілометра [7-10]. Вимірювання здійснювались на сітковій та верхній стороні аркуша у паралельному та перпендикулярному напрямку щодо відливу паперу; довжина трасування становила 4 мм.
Результати вимірювань приведено в табл. 1, графіки шорсткості паперу наведено на рис. 1-8.

Мікрогеометрію поверхні двох видів паперу на основі профілографування можна охарактеризувати наступним чином: верхня сторона одношарового паперу

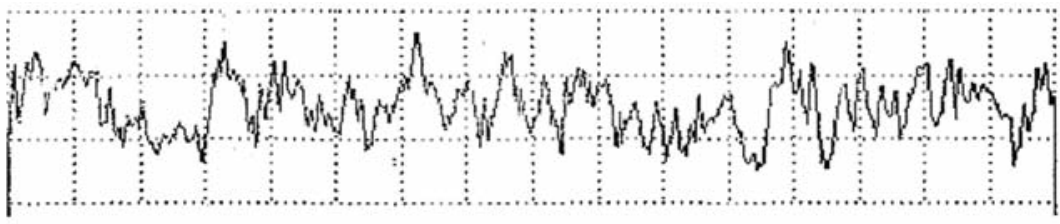

Рис. 3. Профілограма поверхні сіткової сторони одношарового паперу паралельно машинному напрямку відливу

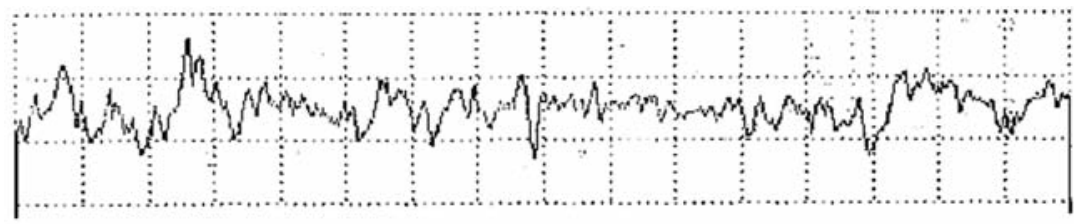

Рис. 4. Профілограма поверхні сіткової сторони одношарового паперу перпендикулярно машинному напрямку відливу

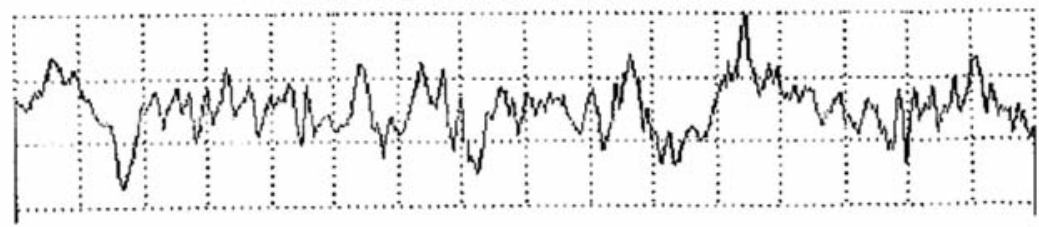

Рис. 5. Профілограма поверхні верхньої сторони двошарового паперу паралельно машинному напрямку відливу

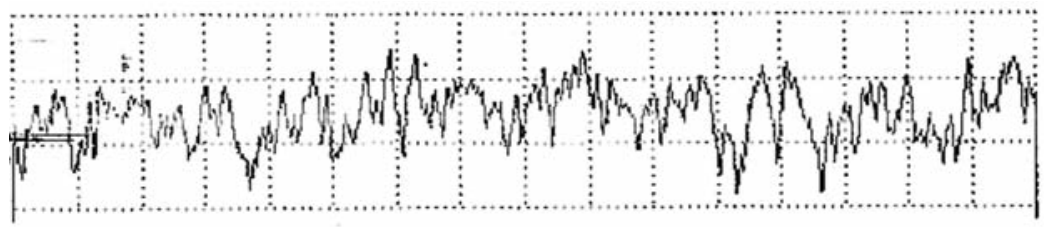

Рис. 6. Профілограма поверхні верхньої сторони двошарового паперу перпендикулярно машинному напрямку відливу 


\section{ТЕХНОЛОГІЧН І ПРО ЦЕ С И}

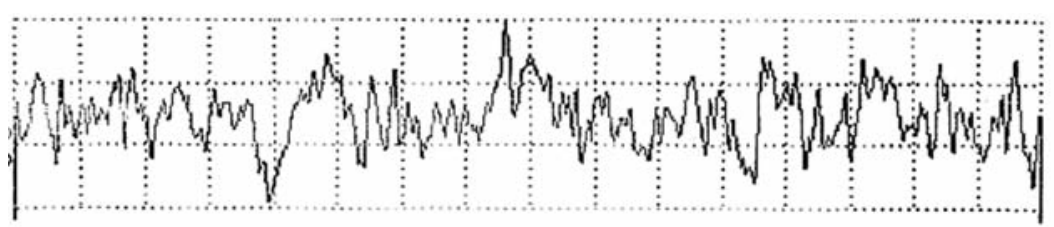

Рис. 7. Профілограма поверхні сіткової сторони двошарового паперу паралельно машинному напрямку відливу

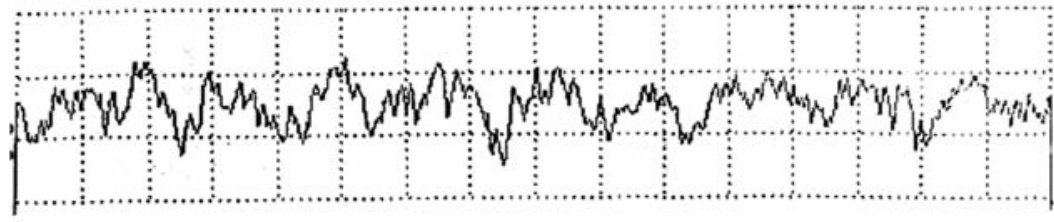

Рис. 8. Профілограма поверхні сіткової сторони двошарового паперу перпендикулярно машинному напрямку відливу

має більшу шорсткість ніж у двошарового за всіма параметрами $\left(\mathrm{R}_{\mathrm{a}}, \mathrm{R}_{\mathrm{z}}, \mathrm{R}_{\max }\right)$, натомість сіткова сторона останнього - має більше нерівностей за параметрами $R_{\mathrm{a}}$ та $\mathrm{R}_{\mathrm{z}}$, ніж сіткова сторона одношарового паперу, однак меншу складову оцінки профілю нерівностей $R_{\max }$. Враховуючи дані щодо шорсткості паперу, отримані за методом Бендстена [3], можна зробити висновок, що одношаровий папір має більшу, ніж двошаровий, випадкову складову нерівностей.

У результаті дослідження кольоровідтворення на різних видах паперу було виявлено, що

Таблиця 2

Колірні характеристики звороту відбитків, отриманих червоною фарбою

\begin{tabular}{|c|c|c|c|c|c|c|c|c|c|}
\hline \multicolumn{5}{|c|}{ Одношаровий папір } & \multicolumn{5}{|c|}{ Двошаровий папір } \\
\hline 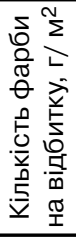 & $L^{*}$ & $a^{*}$ & $b^{\star}$ & $\Delta \mathrm{E}$ & 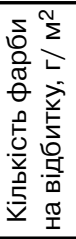 & $L^{*}$ & $a^{*}$ & $b^{*}$ & $\Delta \mathrm{E}$ \\
\hline 1,30 & 89,21 & 4,65 & 1,25 & 3,06 & 1,25 & 89,03 & 4,79 & 1,04 & 3,46 \\
\hline 1,52 & 89,04 & 3,87 & 1,34 & 3,47 & 1,49 & 89,00 & 4,26 & 1,25 & 3,57 \\
\hline 1,86 & 89,09 & 4,26 & 0,55 & 3,49 & 1,86 & 88,98 & 4,01 & 0,78 & 3,80 \\
\hline 2,33 & 89,12 & 3,08 & 0,31 & 4,09 & 2,33 & 88,94 & 3,03 & $-0,85$ & 5,01 \\
\hline 2,60 & 88,74 & 2,52 & $-1,00$ & 5,29 & 2,60 & 88,18 & 1,22 & $-0,79$ & 6,50 \\
\hline
\end{tabular}




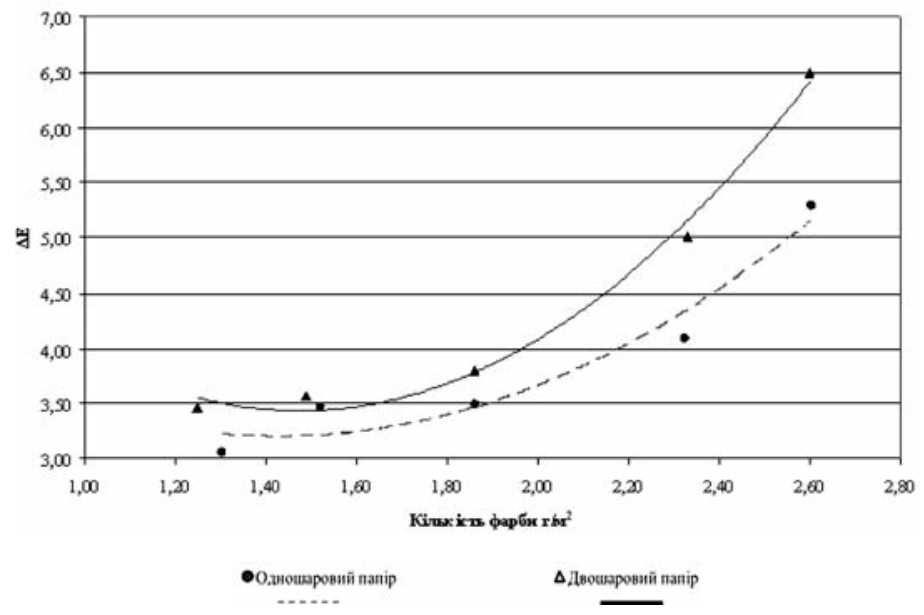

Рис. 9. Залежність $\Delta \mathrm{E}$ зворотного боку паперу від кількості червоної фарби

колірний зсув між одно- та двошаровим папером при однаковій товщині фарбового шару $є$ незначним $-\Delta \mathrm{E}$ не більше трьох [3]. Але при двосторонньому друці варто враховувати величину перебивання на зворот, оскільки суттєве перебивання може спотворювати колір зображення на зворотному боці.
Для дослідження явища перебивання було виміряно колірні характеристики звороту відбитків та порівняно з кольором чистого паперу. Отримані значення колірного зсуву звороту відбитків відносно чистого паперу для трьох кольорів фарб наведено в табл. 2-4. Графіки залежності $\Delta \mathrm{E}$ від товщини фарбового шару представлено на рис. 9-11.

Колірні характеристики звороту відбитків, отриманих жовтою фарбою

\begin{tabular}{|c|c|c|c|c|c|c|c|c|c|}
\hline \multicolumn{5}{|c|}{ Одношаровий папір } & \multicolumn{5}{|c|}{ Двошаровий папір } \\
\hline 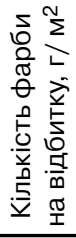 & $L^{*}$ & $a^{*}$ & $b^{\star}$ & $\Delta \mathrm{E}$ & 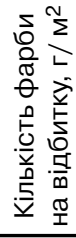 & $\mathrm{L}^{*}$ & $a^{*}$ & $b^{*}$ & $\Delta \mathrm{E}$ \\
\hline 1,30 & 91,45 & 4,167 & 5,337 & 3,71 & 1,30 & 90,763 & 3,803 & 5,503 & 4,15 \\
\hline 1,49 & 91,40 & 3,717 & 5,360 & 3,91 & 1,49 & 90,763 & 3,933 & 5,580 & 4,16 \\
\hline 1,67 & 91,22 & 4,047 & 5,690 & 4,12 & 1,77 & 90,023 & 3,180 & 5,340 & 4,61 \\
\hline 2,23 & 88,84 & 1,18 & $-1,00$ & 6,07 & 2,20 & 88,270 & 0,930 & 4,183 & 6,40 \\
\hline 2,57 & 88,10 & 1,08 & $-1,38$ & 6,74 & 2,52 & 87,880 & 1,120 & $|-1,067|$ & 6,87 \\
\hline
\end{tabular}




\section{Т ЕХНОЛОГІ Ч Н І П РО ЦЕ С И}

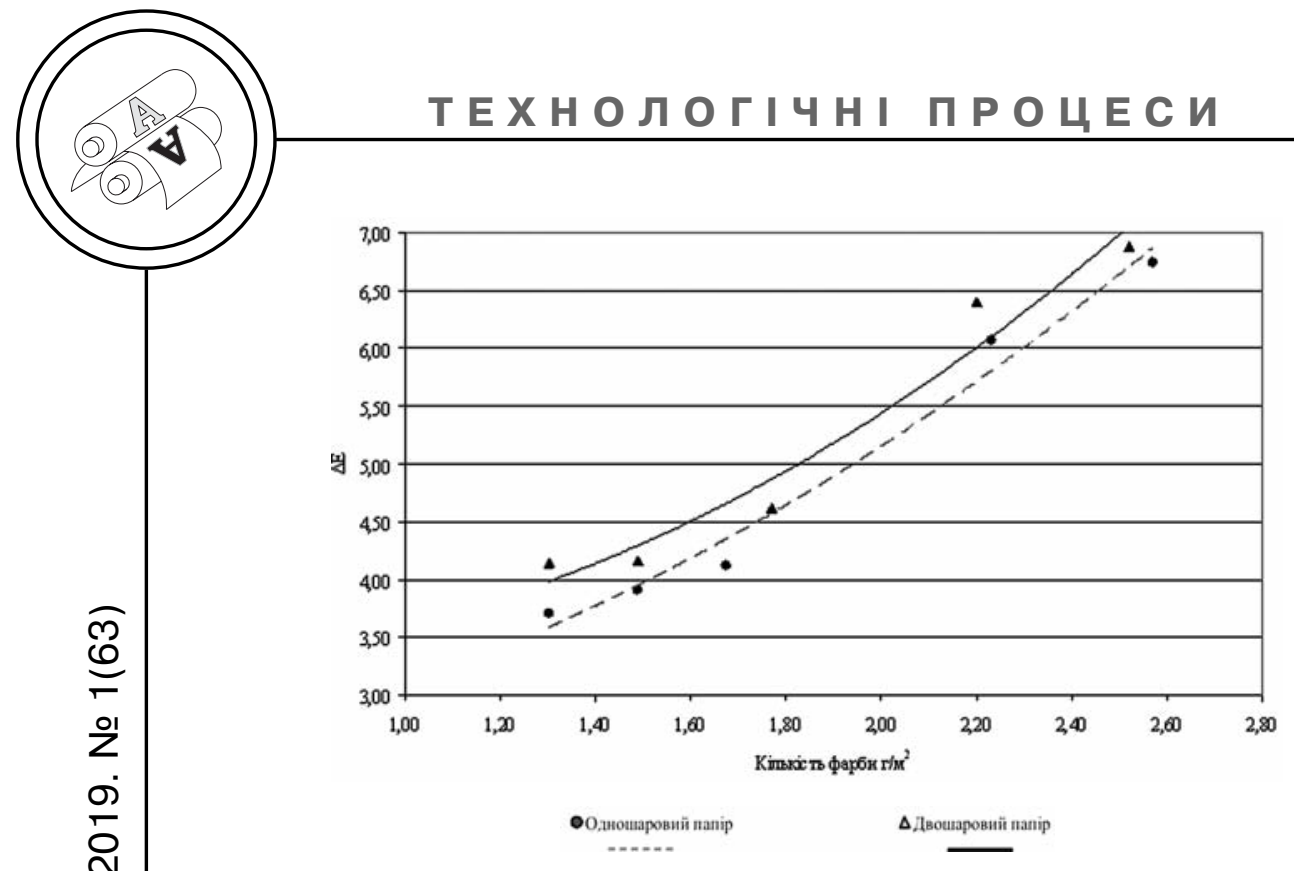

Рис. 10. Залежність $\Delta \mathrm{E}$ зворотного боку паперу від кількості жовтої фарби

\section{Висновки}

При дослідженні явища перебивання фарби на зворот відбитка, виявлено, що найбільший колірний зсув відносно чистого паперу спостерігається для відбитків, отриманих синьою фарбою. На- томість найменше перебивання прослідковується на відбитках із червоною фарбою. Враховуючи, що в'язкість, яка може бути важливим фактором перебивання на зворот, більша у синьої фарби, що мало б призводити

Таблиця 4

Колірні характеристики звороту відбитків, отриманих синьою фарбою

\begin{tabular}{|c|c|c|c|c|c|c|c|c|c|}
\hline \multicolumn{5}{|c|}{ Одношаровий папір } & \multicolumn{5}{|c|}{ Двошаровий папір } \\
\hline 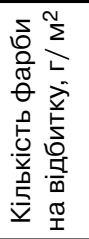 & $L^{*}$ & $a^{*}$ & $b^{*}$ & $\Delta \mathrm{E}$ & 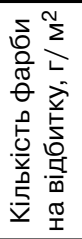 & $L^{*}$ & $a^{*}$ & $b^{*}$ & $\Delta \mathrm{E}$ \\
\hline 1,12 & 89,39 & 1,17 & $-0,90$ & 5,75 & 1,40 & 88,95 & 0,99 & $-0,95$ & 6,27 \\
\hline 1,77 & 88,80 & 1,32 & $-0,98$ & 5,99 & 1,58 & 88,94 & 0,93 & $-0,92$ & 6,31 \\
\hline 1,86 & 88,49 & 1,44 & $-0,93$ & 6,06 & 2,23 & 88,35 & 1,08 & $-0,93$ & 6,54 \\
\hline 2,05 & 88,54 & 1,50 & $-1,14$ & 6,09 & 2,51 & 88,08 & 1,22 & $-0,86$ & 6,59 \\
\hline 2,23 & 88,57 & 1,21 & $-1,07$ & 6,23 & 2,79 & 88,41 & 0,70 & $-0,84$ & 6,72 \\
\hline 2,51 & 88,26 & 1,16 & $-1,17$ & 6,49 & & & & & \\
\hline 2,88 & 88,09 & 1,02 & $-1,213$ & 6,70 & & & & & \\
\hline
\end{tabular}




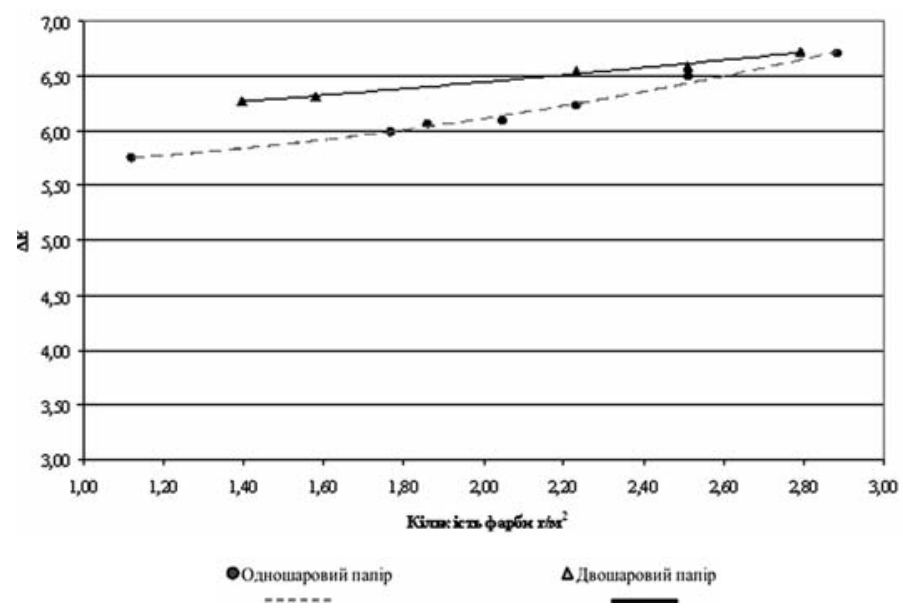

Рис. 11. Залежність $\Delta \mathrm{E}$ зворотного боку паперу від кількості синьої фарби

до протилежного результату (більшого перебивання червоної, менш в'язкої фарби) зрозуміло, що цей фактор не був вирішальним. На нашу думку, менше перебивання червоної фарби можна пояснити наявністю червоного барвника у паперовій масі для банкнотного паперу номіналом 10 грн., що нівелює перебивання фарби на зворот.

Для обох видів паперу простежується майже лінійне збільшення колірного зсуву звороту відбитка відносно збільшення кількості нанесеної фарби. На зво- роті двошарового паперу спостерігається дещо більше проступання фарби, тобто колірний зсув відносно чистого паперу $є$ більшим, ніж на одношаровому папері. Поясненням цього факту може бути дещо менша непрозорість двошарового паперу порівняно з одношаровим.

Враховуючи незначне перебивання фарби на зворот, при розробленні дизайну банкнот варто надавати перевагу подібним за кольором сюжетам, як з однієї, так і з іншої сторони банкноти.

\section{Список використаних джерел}

1. Кейси Д. П. Свойства бумаги и ее переработка / Д. П. Кейси. М.: «Гослесбумиздат», 1960, 650 с.

2. Кожевников С. Химия и технология СКИФ для бумаги / С. Кожевников, І. Ковернинский. М: Изд-во Московского государственного университета леса, 2010. 91 с.

3. Киричок Т. Ю. Дослідження кольоровідтворення на одно- та двошаровому папері спеціального призначення / Т. Ю. Киричок, В. М. Нестеренко, Н. Л. Талімонова // Технологія і техніка друкарства: зб. наук. праць. 2011. № 3(33). C. 17-27. DOI: https://doi.org/10.20535/2077-7264.3(33).2011.52153.

4. Киричок П. О. Методи захисту цінних паперів та документів суворого обліку / П. О. Киричок, Ю. М. Коростіль, А. В. Шевчук. К.: ВПІ ВПК «Політехніка», 2008. 368 с. 
5. Шевчук А. В. Захист друкованої продукції за допомогою змішування фарб / А. В. Шевчук, 3. Есенфельд // Друкарство. 2000. № 4(33). С. 68-71.

6. Kyrychok T. Determining special features in the topography of paper with water marks at the micro- and nanolevels / T. Kyrychok, T. Klymenko, N. Talimonova, K. Svezhentsova // Eastern-European Journal of Enterprise Technologies. 2019. 2(12-98). P. 28-35.

7. Киричок П. О. Зміцнення поверхонь металевих деталей: Навч. посіб. / П. О. Киричок, В. Г. Олійник, Т. Ю. Киричок. К.: Преса України, 2004. 240 с.

8. Шероховатость поверхности. Параметры и характеристики: ГОСТ 2789-73. ГОСТ 2789-73. [Чинний від 1973-04-23]. (Міждержавний стандарт).

9. Средства измерений шероховатости поверхности профильным методом. Профилографы-профилометры контактные. Типы и параметры: ГОСТ 19300-86. ГОСТ 19300-86. [Чинний від 1987-07-01]. (Міждержавний стандарт).

10. Майданюк С. Модуль для вимірювання фасонних профілів / С. В. Майданюк, О. А. Плівак, Р. А. Бекмурадов // Вісник ЖДТУ. 2007. № 2(41). С. $15-18$.

\section{References}

1. Keysi, D. P. (1960). Svoystva bumagi i ee pererabotka. Moscow: 'Goslesbumizdat', 650 p. [in Russian].

2. Kozhevnikov, S. \& Koverninskiy, I. (2010). Khimiya i tekhnologiya SKIF dlya bumagi. Moscow: Izd-vo Moskovskogo gosudarstvennogo universiteta lesa, 91 p. [in Russian].

3. Kyrychok, T. Yu. \& Nesterenko, V. M. \& Talimonova, N. L. (2011). Doslidzhennia kolorovidtvorennia na odno- ta dvosharovomu paperi spetsialnoho pryznachennia. Journal of Tekhnolohiia i tekhnika drukarstva, 3(33), 17-27. DOI: https://doi.org/10.20535/2077-7264.3(33).2011.52153 [in Ukrainian].

4. Kyrychok, P. O. \& Korostil, Yu. M. \& Shevchuk, A. V. (2008). Metody zakhystu tsinnykh paperiv ta dokumentiv suvoroho obliku. Kyiv: VPI VPK 'Politekhnika', 368 p. [in Ukrainian].

5. Shevchuk, A. V. \& Esenfeld, Z. (2000). Zakhyst drukovanoi produktsii za dopomohoiu zmishuvannia farb. Journal of Drukarstvo, 4(33), 68-71 [in Ukrainian].

6. Kyrychok, T. \& Klymenko, T. \& Talimonova, N. \& Svezhentsova, K. (2019). Determining special features in the topography of paper with water marks at the micro- and nanolevels. Eastern-European Journal of Enterprise Technologies, 2(12-98), 28-35 [in English].

7. Kyrychok, P. O. \& Oliinyk, V. H. \& Kyrychok, T. Yu. (2004). Zmitsnennia poverkhon metalevykh detalei. Kyiv: Presa Ukrainy, 240 p. [in Ukrainian].

8. Sherokhovatost' poverkhnosti. Parametry i kharakteristiki. GOST 278973. GOST 2789-73. [Chynnyi vid 23.04.1973] [in Russian].

9. Sredstva izmereniy sherokhovatosti poverkhnosti profil'nym metodom. Profilografy-profilometry kontaktnye. Tipy i parametry. GOST 19300-86. GOST 19300-86. [Chynnyi vid 01.07.1987] [in Russian].

10. Maidaniuk, S. V. \& Plivak, O. A. \& Bekmuradov, R. A. (2007). Modul dlia vymiriuvannia fasonnykh profiliv. Journal of Visnyk ZhDTU, 2(41), 15-18 [in Ukrainian]. 
Исследованы физико-механические, цветовые характеристики двухслойной банкнотной бумаги, микрогеометрия поверхности бумажного полотна и явление перебивания краски на оборот оттиска.

Ключевые слова: банкнотная бумага; перебивание; печатная краска; микрогеометрия поверхности бумаги; цвет.

The aim of this work is to investigate the physicomechanical and color characteristics of two-layer banknote paper, as well as microgeometry of surface of the paper and the transfer of ink to reverse side.

Keywords: banknote paper; interruption; printing ink; microgeometry of the paper surface; color.

Рецензент - В. М. Скиба, канд. техн. наук, доцент, КПІ ім. Ігоря Сікорського

Надійшла до редакції 31.03.19 